\title{
NMDA Receptor Content of Synapses in Stratum Radiatum of the Hippocampal CA1 Area
}

\author{
Claudia Racca, ${ }^{1}$ F. Anne Stephenson, ${ }^{2}$ Peter Streit,, ${ }^{3}$ J. David B. Roberts, ${ }^{1}$ and Peter Somogyi ${ }^{1}$ \\ ${ }^{1}$ Medical Research Council Anatomical Neuropharmacology Unit, Oxford University, Oxford OX1 3TH, United Kingdom, \\ 2School of Pharmacy, University of London, London WC1N 1AX, United Kingdom, and 3/nstitut für Hirnforschung, \\ Universität Zürich, $\mathrm{CH}$-8057 Zürich, Switzerland
}

Glutamate receptors activated by NMDA (NMDARs) or AMPA (AMPARs) are clustered on dendritic spines of pyramidal cells. Both the AMPAR-mediated postsynaptic responses and the synaptic AMPAR immunoreactivity show a large intersynapse variability. Postsynaptic responses mediated by NMDARs show less variability. To assess the variability in NMDAR content and the extent of their coexistence with AMPARs in Schaffer collateral-commissural synapses of adult rat CA1 pyramidal cells, electron microscopic immunogold localization of receptors has been used. Immunoreactivity of NMDARs was detected in virtually all synapses on spines, but AMPARs were undetectable, on average, in $12 \%$ of synapses. A proportion of synapses had a very high AMPAR content relative to the mean content, resulting in a distribution more skewed toward larger values than that of NMDARs. The variability of synaptic NMDAR content [coefficient of variation (CV), 0.64-0.70] was much lower than that of the AMPAR content (CV, 1.17-1.45). Unlike the AMPAR content, the NMDAR content showed only a weak correlation with synapse size. As reported previously for AMPARs, the immunoreactivity of NMDARs was also associated with the spine apparatus within spines. The results demonstrate that the majority of the synapses made by CA3 pyramidal cells onto spines of CA1 pyramids express both NMDARs and AMPARs, but with variable ratios. A less-variable NMDAR content is accompanied by a wide variability of AMPAR content, indicating that the regulation of expression of the two receptors is not closely linked. These findings support reports that fast excitatory transmission at some of these synapses is mediated by activation mainly of NMDARs.

Key words: hippocampus; spine; immunocytochemistry; electron microscopy; NMDA receptor; AMPA receptor; glutamate receptor; spine apparatus
The excitatory synapses made by boutons of hippocampal CA3 pyramidal cells with dendritic spines of CA1 pyramids show a large variability in size (Harris and Kater, 1994; Boyer et al., 1998) and also in the evoked postsynaptic currents (Kullmann, 1994). Release of glutamate activates NMDA- and AMPA-type ionotropic glutamate receptors (NMDAR and AMPAR, respectively) at these synapses (Collingridge et al., 1983), and the activity-dependent change in synaptic responses has been studied extensively (Bliss and Collingridge, 1993). One possible mechanism proposed to contribute to the activity-dependent change in the size of synaptic responses is a change in the number of functional synaptic AMPARs (Isaac et al., 1995; Liao et al., 1995, 1999; Durand et al., 1996; Gomperts et al., 1998; O’Brien et al., 1998; Petralia et al., 1999; Shi et al., 1999; Takumi et al., 1999b).

Quantitative immunocytochemical studies of synaptic AMPAR levels show great variability of receptor content at individual synapses (Nusser et al., 1998; Petralia et al., 1999; Takumi et al., 1999 b), suggesting a wide range of upregulation or downregulation of receptor numbers and synaptic responses. A large proportion of synapses in adult rats contains very low or undetectable

Received Sept. 7, 1999; revised Jan. 20, 2000; accepted Jan. 26, 2000.

P.S. was supported by the Swiss National Foundation Grant 31-49385.96. We thank Dr. Zoltan Nusser and Gabor Nyiri for their critical comments on a previous version of this manuscript. We are grateful to Dr. R. J. Wenthold (National Institute on Deafness and Other Communication Disorders/National Institutes of Health) for the anti-NR2A/B and anti-GluR2/3 antibodies.

Dr. Racca's present address: Laboratory of Neurochemistry, National Institute on Deafness and Other Communication Disorders, National Institutes of Health, Building 36, Room 5D08, 36 Convent Drive, Bethesda, MD 20892.

Copyright (C) 2000 Society for Neuroscience $0270-6474 / 00 / 202512-11 \$ 15.00 / 0$ levels of AMPARs. If these synapses had a significant level of NMDARs, these would mainly mediate fast glutamatergic neurotransmission. Indeed, in the developing hippocampus, at some synapses only an NMDAR-mediated response could be detected (see Malenka and Nicoll, 1997), supporting the proposal that a change in synaptic efficacy is caused by insertion of synaptic AMPARs. Recently, a rapid appearance of AMPARs has been shown in spines after tetanic stimulation of hippocampal slice cultures (Shi et al., 1999).

Because of the different properties of AMPARs and NMDARs, their absence or presence, or their ratio when they are both present, has implications not only for the development of synaptic connections and the change in synaptic efficacy but also for the normal functions of the hippocampus. In contrast to the highly variable level of expression of AMPARs, it was suggested that most type I synapses contain NMDARs in the CA1 area (Petralia et al., 1999; Takumi et al., 1999b). Takumi et al. (1999b) reported that synapses of a diameter less than $\sim 180 \mathrm{~nm}$ lack AMPARs and that above this value the ratio of AMPAR-toNMDAR content increases linearly with synapse diameter. This was caused by the increased AMPAR content of larger synapses, as shown both in the hippocampus (Nusser et al., 1998) and in the neocortex (Kharazia and Weinberg, 1999), whereas the calculated total NMDAR content correlated only weakly with the diameter of synapses.

In the present study, we reexamined the variability of AMPAR and NMDAR immunoreactivity and the relationship of their levels to the size of synapses reconstructed from serial electron microscopic sections in adult rats. The data made it possible to 
Table 1. Comparison of postembedding immunoreactions used for the analyzed data

Nusser et al. (1998) $\quad$ Present study ${ }^{a}$

\begin{tabular}{|c|c|c|}
\hline \multicolumn{3}{|l|}{ Blocking solution } \\
\hline $\begin{array}{l}50 \mathrm{~mm} \text { Tris- } \mathrm{HCl}, \mathrm{pH} 7.4 \\
0.3 \% \mathrm{NaCl} \text { (TBS), } \\
0.03 \% \text { Triton-X 100, and }\end{array}$ & $\begin{array}{l}20 \% \text { normal goat serum } \\
\text { (NGS, Vector) }\end{array}$ & $\begin{array}{l}2 \% \text { human albumin } \\
\text { (HA, Sigma) }\end{array}$ \\
\hline $\begin{array}{l}\text { Primary antibody incubatior } \\
50 \mathrm{~mm} \text { Tris-HCl, pH 7.4, } \\
0.3 \% \mathrm{NaCl} \text { (TBS), }\end{array}$ & & \\
\hline $0.03 \%$ Triton-X 100 , and & $2 \% \mathrm{NGS}$ & $2 \% \mathrm{HA}$ \\
\hline Temperature & Room & $28^{\circ} \mathrm{C}$ \\
\hline
\end{tabular}

${ }^{a}$ Data for AMPARs were used for rats 1 and 2 from this study.

${ }^{b}$ Data for NMDARs were obtained in the present study from the same blocks for rats 1 and 2 as used by Nusser et al. (1998) and for both AMPARs and NMDARs from an additional animal, rat 3.

compare the receptor content of synapses in spines from the same area of the CA1 region. The results show that virtually all synapses on spines contain NMDARs and that the immunoreactivity of the two receptors is distributed differently across the spine population.

\section{MATERIALS AND METHODS}

Preparation of tissue. Three adult Wistar rats ( $\sim 150 \mathrm{gm}$; rat 1 , rat 2 , and rat 3; Charles River) were anesthetized with Sagatal (pentobarbitone sodium, $220 \mathrm{mg} / \mathrm{kg}$, i.p.) and perfused through the heart with $0.9 \% \mathrm{NaCl}$ followed by fixative containing $4 \%$ paraformaldehyde, $0.05 \%$ glutaraldehyde, and $\sim 0.2 \%$ picric acid in $0.1 \mathrm{M}$ phosphate buffer, $\mathrm{pH} 7.4$ (PB), for 15-25 min. After perfusion the brains were removed, and blocks from the dorsal hippocampus were cut out and washed in several changes of PB. Freeze substitution and low-temperature embedding were performed as described previously (Baude et al., 1993; Nusser et al., 1995). For cryoprotection, $500-\mu \mathrm{m}$-thick sections cut with a vibratome were placed either into $1 \mathrm{M}$ sucrose solution in $\mathrm{PB}$ for $2 \mathrm{hr}$ or in 10,20 , or $30 \%$ glycerol in $0.1 \mathrm{M}$ Tris-maleate buffer, $\mathrm{pH} 7.4$, overnight. They were then slammed onto copper blocks cooled in liquid $\mathrm{N}_{2}$. This was followed by freeze-substitution with methanol and embedding in Lowicryl HM 20 resin (Chemische Werke Lowi GmbH).

Antibodies. All antibodies used have been described previously. They were all affinity purified. The concentrations of primary antibodies were chosen such that they resulted in low-background labeling as assessed either on empty resin or over neuronal mitochondria. Polyclonal antibodies to a synthetic peptide, corresponding to amino acid residues Cys17-35 of the extracellular domain of all rat NR1 subunit splice forms and conjugated to the carrier protein thyroglobulin, were raised in rabbit and affinity purified as described by Chazot et al. (1995) and Chazot and Stephenson (1997). These antibodies are referred to as ab-NR1-pan. They recognized in immunoblots a single band at $120 \mathrm{kDa}$ in human embryonic kidney (HEK)-293 cells transfected with NR1-1a or NR1-4b cDNAs and two bands at 120 and $85 \mathrm{kDa}$ in membrane prepared from mouse forebrain. The ab-NR1-pan antibodies were used at a concentration of $10 \mu \mathrm{g} / \mathrm{ml}$. Polyclonal antibodies to a 20 amino acid peptide, corresponding to the $\mathrm{C}$-terminal sequence of the rat NR2A subunit, were raised in rabbit and affinity purified (Petralia et al., 1994a). The antibodies are referred to as ab-NR2A/B and were used at a concentration of 2 $\mu \mathrm{g} / \mathrm{ml}$. The antibodies were shown to recognize in immunoblots both NR2A and NR2B subunits in HEK-293 cells transfected with these subunit cDNAs and to recognize a single band at $172 \mathrm{kDa}$ in membrane prepared from rat brain (Petralia et al., 1994a). Polyclonal antibodies to a fusion protein, corresponding to amino acid residues 724-781 of the extracellular domain of the rat glutamate receptor 1 (GluR1)-flop subunit, were raised in rabbit and used at a concentration of $7.5-15 \mu \mathrm{g} / \mathrm{ml}$ (Nusser et al., 1998). The antibodies were shown to recognize in immunoblots both the flip and the flop splice variants of the GluR1-4 subunits in COS-7 cells transfected with GluR1-4 subunit cDNAs and to recognize a single band at $\sim 110 \mathrm{kDa}$ in rat brain membranes (Nusser et al., 1998). The antibodies are referred to as ab-pan-AMPAR. Polyclonal antibodies to a 13 amino acid synthetic peptide, corresponding to the $\mathrm{C}$-terminal sequence of the rat GluR2/3 subunits, were raised in rabbit and used at a concentration of $2 \mu \mathrm{g} / \mathrm{ml}$ (Wenthold et al., 1992). The antibodies were shown to recognize in immunoblots both the GluR2 and GluR3 subunits in COS-7 cells transfected with cDNAs for these subunits and to recognize a single band at $108 \mathrm{kDa}$ in membrane extracts from rat brain (Wenthold et al., 1992). The antibodies are referred to as ab-GluR2/3, although they also recognize the GluR4c subunit. The latter however is only expressed in the cerebellum (Gallo et al., 1992). A monoclonal antibody to a synthetic peptide used by Wenthold et al. (1992), corresponding to the C-terminal sequence of the rat GluR2 subunit, was raised in mouse and used at a concentration of $0.2 \mu \mathrm{g} / \mathrm{ml}$ (Nusser et al., 1994; Ottiger et al., 1995). The antibody was shown to recognize in immunoblots a single band at $105 \mathrm{kDa}$ in membrane extracts from rat brain (Nusser et al., 1994; Ottiger et al., 1995). The antibody is referred to as ab-1F1. Mixtures of primary antibodies (ab-NR1-pan and ab-NR2A/B or ab-pan-AMPAR and ab-GluR2/3) were used to increase the labeling intensity for quantification of synaptic labeling.

Postembedding immunocytochemistry. Lowicryl resin-embedded ultrathin sections (of 70-80 nm thickness) were picked up on either pioloform-coated nickel slot grids or pioloform-coated 400 mesh nickel grids. Table 1 outlines the differences between the protocol used in Nusser et al. (1998) and that used in the present study. The grids were incubated on drops of blocking solution (see Table 1), followed by incubation on drops of primary antibodies as described in Table 1. After the incubation with primary antibodies, the sections were washed in TBS (three times for $10 \mathrm{~min}$ each) and in $50 \mathrm{~mm}$ Tris-HCl, $\mathrm{pH} 7.4$, containing $0.9 \% \mathrm{NaCl}$ (TBS*; once for $10 \mathrm{~min}$ ) and incubated on drops of goat anti-rabbit IgG or goat anti-mouse IgG coupled to $10 \mathrm{~nm}$ gold particles (British BioCell Int.). The secondary antibodies were diluted 1:100 in TBS* containing $0.05 \%$ polyethylene glycol 20000 (BDH; Merck) and $2 \% \mathrm{HA}$ for $2 \mathrm{hr}$ at $28^{\circ} \mathrm{C}$. After additional washing in TBS* (three times for $10 \mathrm{~min}$ each) and $\mathrm{PB}$ containing $0.9 \% \mathrm{NaCl}$ (PBS; once for $10 \mathrm{~min}$ ), the sections were post-fixed in $2 \%$ glutaraldehyde in PBS for 2 min at room temperature and then washed in bidistilled water (three times for 10 min each). Finally, the sections were contrasted with saturated aqueous uranyl acetate followed by staining with lead citrate.

Controls. Grids incubated with specific primary antibodies to NMDARs showed an overall labeling of $6.91 \pm 1.57$ particles $/ \mu \mathrm{m}^{2}$ (mean $\pm \mathrm{SD} ; n=3$ rats), most particles being associated with type I synapses. In some cases, postembedding immunocytochemistry was performed as described above except the primary antibodies were omitted. The density of particles, when the primary antibodies were omitted, was $0.138 \pm 0.012$ particles $/ \mu \mathrm{m}^{2}$ (mean $\pm \mathrm{SD} ; n=3 \mathrm{rats}$ ), showing that nonspecific attachment of the secondary antibody-gold conjugate did not make a significant contribution to the synaptic labeling. In other cases, primary antibodies were replaced by nonimmune rabbit IgG (I-5006; Sigma) at a concentration of $12 \mu \mathrm{g} / \mathrm{ml}$, equal to that of the total protein content of the mixture of rabbit antibodies to NMDARs used in the present study. Unfortunately, the IgG content of these antibody solutions is not known, and it is likely that some of the total protein is not $\mathrm{IgG}$. Therefore, it is very likely that the $\mathrm{IgG}$ concentration of the nonimmune rabbit $\operatorname{IgG}$ solution is higher than that of the specific antibody solution. Nevertheless, this control provides an upper limit of the gold density deposited nonspecifically as a result of the attachment of rabbit $\operatorname{IgG}$ to the sections by means other than via their epitope recognition sites. Control incubations using nonimmune rabbit IgG resulted in a particle density of $2.05 \pm 0.88$ particles $/ \mu \mathrm{m}^{2}$ (mean $\pm \mathrm{SD} ; n=3$ rats). Particles 
were not associated with any particular subcellular structure. In some other cases, the specific primary antibodies were replaced with $5 \%$ normal rabbit or normal mouse serum. These incubations resulted in a relatively high number of particles nonselectively distributed on the sections, because the total Ig concentration of this solution is higher than that of primary antibodies. However, there was no preferential labeling of the type I synapses as on the sections incubated with the specific antibodies.

The above measurements were obtained from photographs at a final magnification of 25,000-29,000 $\times$. For all control conditions, four sections for each one of the three rats were examined, and for each rat a field of $36 \mu \mathrm{m}^{2}$ (nonimmune rabbit IgG) or $136 \mu \mathrm{m}^{2}$ (no primary antibody) in the stratum radiatum of the CA1 area was randomly photographed.

Double-labeling postembedding immunocytochemistry. Ultrathin sections picked up on pioloform-coated 400 mesh nickel grids were reacted as described above. Briefly, the grids were incubated in a mixture of primary antibodies consisting of ab-1F1, ab-NR1-pan, and ab-NR2A/B. A mixture of goat anti-rabbit IgG coupled to 10 or $20 \mathrm{~nm}$ gold particles and goat anti-mouse IgG coupled to 5 or $10 \mathrm{~nm}$ gold particles were used as secondary antibodies. The simultaneous use of antibodies raised in two different host species was chosen, because the sequential application of the anti-AMPAR and anti-NMDAR antibodies, all raised in rabbits, using the paraformaldehyde vapor protocol (Petralia et al., 1999) resulted in a significant attenuation of the signal for the second set of antibodies (C. Racca and P. Somogyi, unpublished observation). We also tried to use the monoclonal antibody (1F1) for the quantification of AMPAR immunoreactivity, but on its own it has provided a weaker signal than the antibody to the same peptide sequence raised in rabbit (ab-GluR2/3). Therefore the latter antibody was the antibody used in the quantification of AMPAR immunolabeling in both Nusser et al. (1998) and the present study. The comparison of labeling resulted in a significant difference in distribution ( $p<0.005$, Kolmogorov-Smirnov test) between the two antibodies. Furthermore, in an additional experiment it was found that the efficiency of anti-NMDAR and anti-AMPAR antibodies appears to be compromised when the two sets of antibodies are used simultaneously (G. Nyiri and P. Somogyi, unpublished observation). Other approaches, such as reacting paired serial sections each immunoprocessed for a single receptor (Valtschanoff et al., 1999), raise problems for quantification particularly of small synapses. Because of the above difficulties the colabeling of the same section for two receptors has been used only for a qualitative investigation and is only dealt with briefly.

Quantification of immunoreactivity. The method to quantify the immunoreactivity was as described by Nusser et al. (1998). The measurements of AMPAR and NMDAR labeling of synapses originated from the same tissue blocks of stratum radiatum of the CA1 area of the three animals (rat 1 , rat 2 , and rat 3 ). Blocks from rat 1 and rat 2 were the same blocks used by Nusser et al. (1998); these authors referred to them as rat-1 and rat-2, respectively. Rat 3 was used for the first time in this study. The reactions for NMDA receptors were performed at the same time for all three animals. Serial ultrathin sections were cut from the CA1 region of the hippocampus, and each series of sections was reacted for NMDA- or AMPA-type glutamate receptors. Areas in the stratum radiatum of the CA1 region were photographed in 19-25 serial sections and printed at a magnification of 30,000-35,000 $\times$. Synapses made by axon terminals with pyramidal cell spines were included in the analysis only if they were fully present within the serially sectioned volume of tissue.

Immunoparticles were counted within the anatomically defined synaptic junctions (Gray, 1959) of all synapses regardless of the plane of the section relative to the synaptic cleft. The length of the junction was also measured on each ultrathin section. Synapses were only included in the area measurement if the synaptic cleft was visible; therefore synapses cut very tangential were omitted. The section thickness was assumed to be 75 $\mathrm{nm}$ on the basis of the interference color of the sections floating on water in the boat of the diamond knife (Harris and Stevens, 1989; Hayat, 1989). The area of the postsynaptic density (PSD) was calculated by multiplying the synaptic length in each section with the estimated average thickness of the electron microscopic section $(75 \mathrm{~nm})$; areas were then summed from all sections through each synapse. The values measured for the PSD area in the CA1 region were consistent with those reported previously (Harris and Kater, 1994; Boyer et al., 1998; Nusser et al., 1998; Shepherd and Harris, 1998).

Tangential distribution of NMDARs within the PSD. Ultrathin sections were picked up on pioloform-coated mesh grids, immunoreacted, photographed, and printed at a final magnification of 100,000-105,000× from two of the animals (rat 1 and rat 2) used in the quantification of
NMDAR content within synapses. Synapses were measured only if the synaptic cleft was visible; therefore synapses cut very tangential were omitted. All gold particles found in the synaptic junctions in each synapse were included. Tangential location of gold particles was measured from the midline of the PSD. The distance between the midline and the edge of the PSD was divided into five bins, each bin corresponding to $10 \%$ of the PSD length in a single section, and each gold particle was assigned to a bin.

\section{RESULTS}

\section{Distribution of NMDARs at synapses of CA1 pyramidal cell spines}

Pyramidal cells in the CA1 area strongly express mRNAs for the NR1, NR2A, and NR2B subunits of the NMDAR (Monyer et al., 1994). These subunits have also been localized by immunocytochemistry (Petralia et al., 1994a,b, 1999; Takumi et al., 1999b). Postembedding quantitative immunogold labeling of serial sections with a mixture of antibodies to the NR1 and NR2A/B subunits showed that in the stratum radiatum, where most spines receive synapses from the Schaffer collateral and commissural projections of CA3 pyramidal cells, virtually all synapses were NMDAR immunopositive (Fig. 1, Table 2). This antibody mixture was used to maximize the labeling intensity (Nusser et al., 1998; Petralia et al., 1999; Takumi et al., 1999b). The serialsection approach (for review, see Nusser, 1999; Takumi et al., $1999 \mathrm{~b}$ ) allowed us to estimate the synaptic area as well as to test the receptor immunoreactivity of the same synapse in each of the sections cut from it, thereby providing a more representative characterization (e.g., Fig. 1A1-A7) than was possible from single sections. Indeed, in single sections, a high proportion of synapses appeared immunonegative (Fig. $1 B, C$ ). As in previous studies in the hippocampus (Petralia et al., 1999; Takumi et al., 1999b) and neocortex (Kharazia and Weinberg, 1997, 1999; Valtschanoff et al., 1999), most immunogold particles were located over the postsynaptic density, the postsynaptic membrane, and the synaptic cleft, suggesting a mostly postsynaptic localization of NMDARs. Detailed analysis of potential presynaptic receptors was not performed because it requires antibodies to intracellular epitopes; the antibody to the NR1 subunit used here was made to an extracellular epitope.

The distributions of immunoreactivity of NMDARs in synapses on spines are shown in Figure 2, $A, C$, and $E$. All synapses were analyzed, irrespective of the plane of the section relative to the synaptic cleft. In all three animals, the distribution of NMDAR immunoreactivity per synapse was skewed toward higher values ( $p<0.001$, Shapiro-Wilk test). There was a weak but significant correlation ( $p<0.01$, Spearman rank correlation) between the synaptic area and the number of immunogold particles for NMDARs (Fig. 3A,C,E). The density of immunolabeling per synapse declined with increasing synaptic area (Fig. 3B,D,F), as reflected by the weak but significant negative correlation of immunoparticle density and synaptic area $(p<0.01$, rats 1,$2 ; p<$ 0.05 , rat 3; Spearman rank correlation).

\section{Comparison of the distribution of NMDARs and AMPARs}

Quantification of AMPARs and NMDARs on the same series of sections on the same grid was not possible to perform. This was because of methodological limitations such as the following: (1) all antibodies providing a high level of labeling of AMPARs and NMDARs were raised in the same host species (rabbits), and (2) the currently available double-labeling protocols [sequential antibody application, see Petralia et al. (1999), or simultaneous 

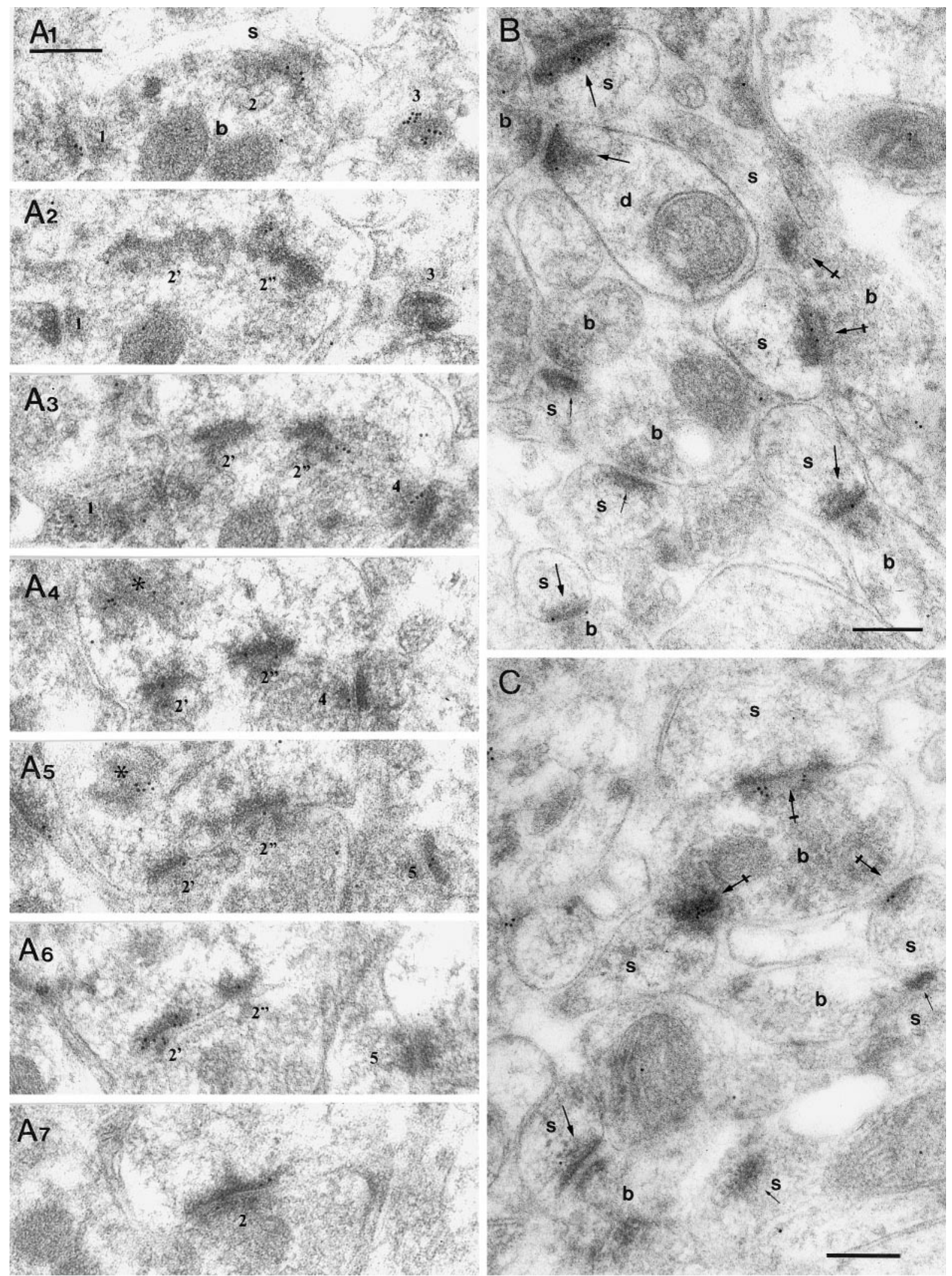

Figure 1. Variability in the NMDA receptor content of synapses on spines of CA1 pyramidal cells in the stratum radiatum. $A 1-A 7$, Electron micrographs of serial sections show the high probability of labeling synapses with a mixture of the antibodies ab-NR1-pan and ab-NR2A/B. All five synapses (1-5) are immunopositive. The spine bearing perforated synapse number $2\left(2^{\prime}, 2^{\prime \prime}\right.$, segments of postsynaptic density) contains a labeled spine apparatus (asterisk; $A 4, A 5) . B, C$, In a single section of type I synapses made by boutons $(b)$ with spines $(s)$ and a dendritic shaft $(d)$, only some synapses $(l a r g e$ arrows) contain immunoparticles; others appear immunonegative (small arrows). The same bouton can form synapses with several spines (crossed arrows). Note that gold particles often cluster at the synapses. Scale bars, $0.2 \mu \mathrm{m}$. 
Table 2. Serial section analysis of synaptic immunogold labelling for NMDARs

\begin{tabular}{|c|c|c|c|}
\hline & Rat 1 & Rat 2 & Rat 3 \\
\hline No. of Analyzed synapses ${ }^{a}$ & 255 & 273 & 225 \\
\hline No. of particles per synapse ${ }^{b}$ & $7.920 \pm 5.52$ & $6.075 \pm 4.06$ & $10.06 \pm 6.45$ \\
\hline Range of particles per synapse & $0-35$ & $0-24$ & $1-31$ \\
\hline$\%$ of Immunonegative synapses & 1.57 & 0.37 & 0 \\
\hline No. of Synapses for area measurement $t^{c}$ & 226 & 240 & 201 \\
\hline Synaptic area $\left(\mu \mathrm{m}^{2}\right)^{b}$ & $0.040 \pm 0.023$ & $0.040 \pm 0.023$ & $0.046 \pm 0.024$ \\
\hline Particle density $\left(\text { No. } / \mu \mathrm{m}^{2}\right)^{b, d}$ & $206.68 \pm 122.4$ & $171.54 \pm 103.8$ & $224.34 \pm 113.3$ \\
\hline
\end{tabular}

${ }^{a}$ All synapses included, irrespective of the plane of the section relative to the synaptic cleft.

${ }^{b}$ Mean $\pm \mathrm{SD}$.

${ }^{c}$ PSD area measured only for synapses sectioned at an angle revealing at least some of the synaptic cleft.

${ }^{d}$ Density $=$ number of particles in a synapse/synaptic area
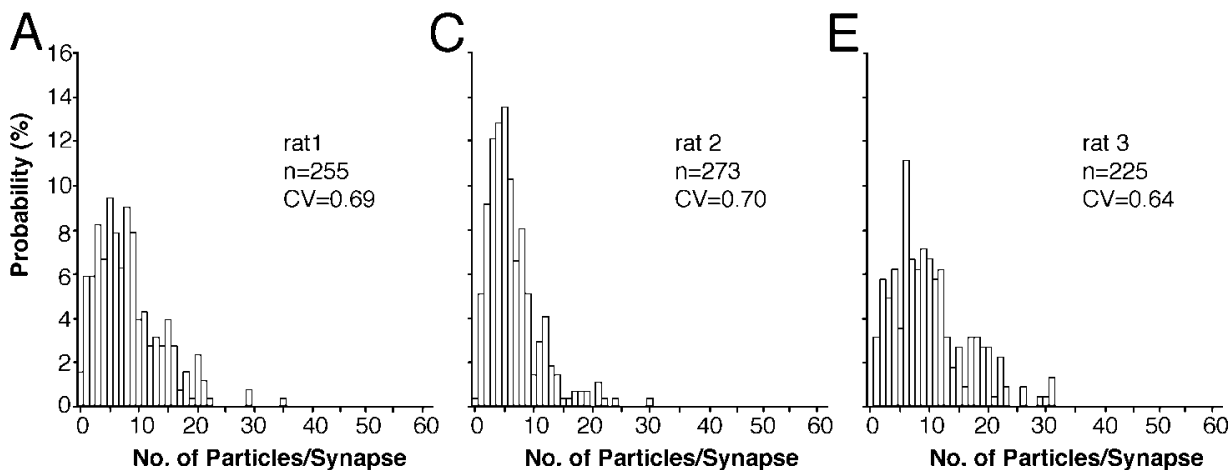

Figure 2. Distribution of synapses on spines according to NMDAR $(A, C, E)$ and AMPAR $(B, D, F)$ immunoreactivity in three adult rats ( $A, B$, rat $1 ; C, D$, rat 2 ; and $E, F$, rat 3 ). The distributions of synapses are skewed toward larger values for both receptors. Virtually all synapses contain NMDAR, but $14.4 \%(B)$, $12.8 \%(D)$, and $9.4 \%(F)$ of synapses are immunonegative for AMPA receptor. The distributions of AMPAR content are more skewed and have a larger coefficient of variation $(C V)$. The sample presented in $D$ contained three synapses having $>60$ particles for AMPAR. Data for $B$ and $D$ are from Nusser et al. (1998).
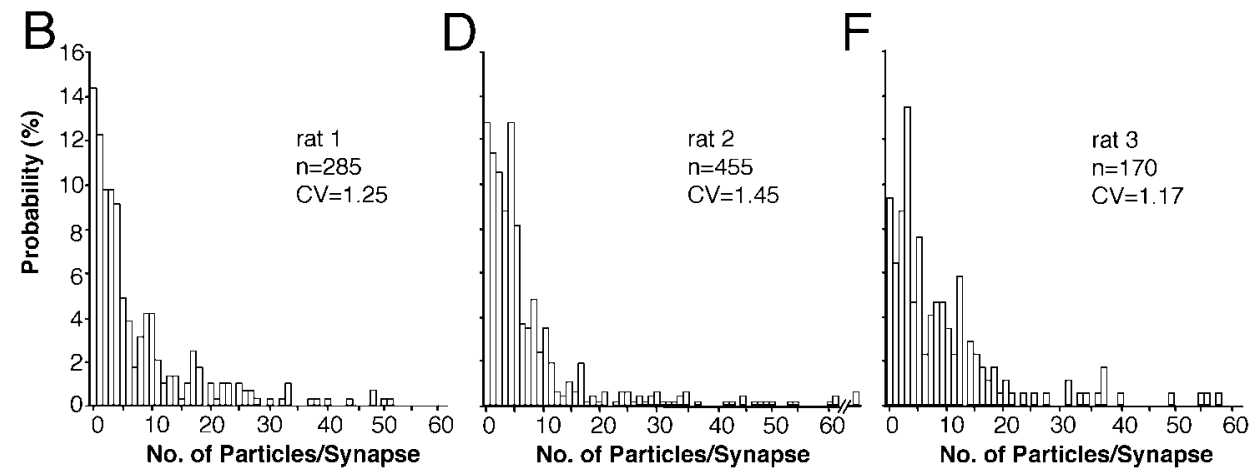

antibody application, see below] resulted in the attenuation of the signal, as compared with single labeling of one receptor only. Therefore, data for the distribution of the two receptors derive from serial sections on different grids but cut from the same tissue block of a small area of CA1 stratum radiatum.

The AMPAR distribution in two of the animals used in the present study (rat 1 and rat 2) has been reported previously by Nusser et al. (1998; their rat-1 and rat-2) from the same tissue blocks used here. In an additional animal (rat 3), we determined the AMPAR distribution using the same mixture of antibodies, ab-GluR2/3 and ab-pan-AMPAR, and similar reaction conditions (see Table 1). A skewed distribution of AMPAR immunoreactivity per spine was obtained ( $p<0.001$, Shapiro-Wilk test; Fig. $2 F$ ) very similar to that reported for rat 1 and rat 2 (Fig. $2 B, D$ ) by Nusser et al. (1998). The mean number of immunoparticles per synapse in rat 3 was $9.37 \pm 10.99(n=170)$. In all examined rats, a proportion of synapses was immunonegative for AMPARs (rat $1,14.38 \%$; rat $2,12.77 \%$; and rat $3,9.41 \%$ ), resulting in a mean proportion of immunonegative synapses of $12.2 \pm 2.5 \%(n=3)$.
As reported previously for rats 1 and 2 [see Nusser et al. (1998); their Fig. $4 B, C]$, a strong correlation $(r=0.86 ; p<0.01 ; n=163)$ between synaptic area and the number of particles per synapse was obtained in rat 3 , and a weak correlation between synaptic area and immunoparticle density was observed $(r=0.37 ; p<$ $0.01 ; n=163$ ).

In summary, the main differences between the distributions of AMPA and NMDA receptor immunoreactivities on spines are (1) the fact that virtually all synapses are immunopositive for NMDARs but not for AMPARs, (2) the much smaller variability of NMDAR content than of AMPAR content (Fig. 2), and (3) a less-skewed distribution of immunoreactivity of NMDAR on spines (skewness, 1.22, 1.75, and 1.01; rats 1, 2, and 3, respectively) than of AMPARs (skewness, 2.17, 3.25, and 2.26; rats 1, 2, and 3 , respectively).

It follows from the above results that AMPARs and NMDARs are colocalized in at least $85-90 \%$ of synapses on spines. Their colocalization in individual synapses could only be confirmed qualitatively because of the properties of the antibodies used and 

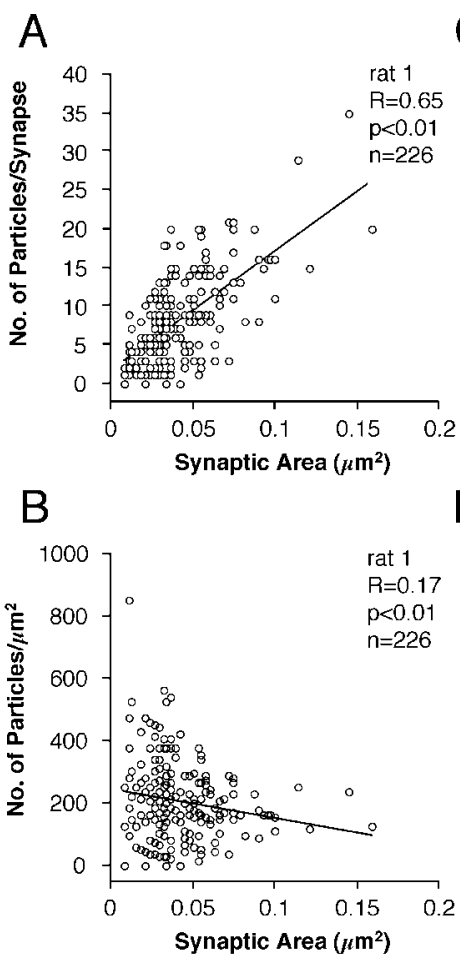

C

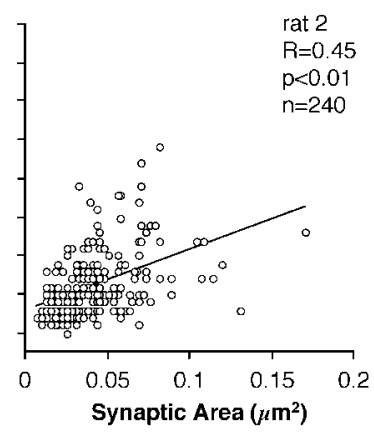

D

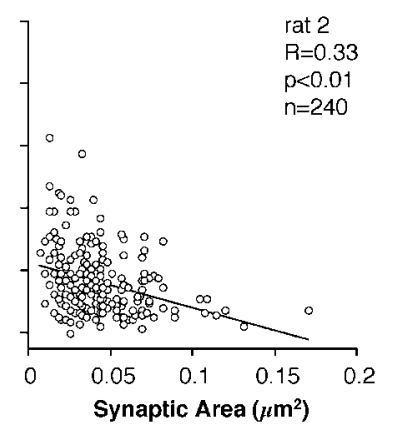

E

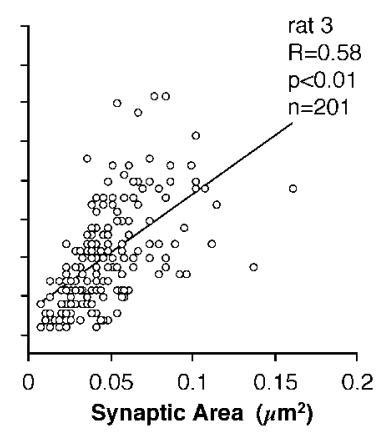

$\mathrm{F}$

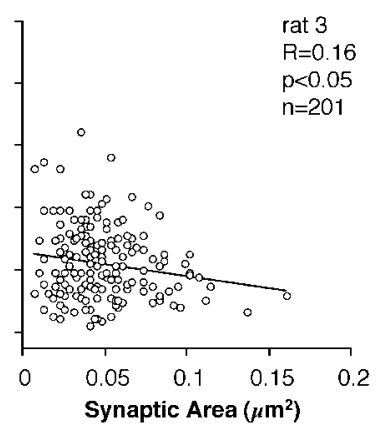

Figure 3. NMDAR immunoparticle density at synapses on spines. $A, C, E$, There is a weak positive correlation between the size and the NMDA receptor immunoparticle content of synapses $(p<0.01$, Spearman rank correlation). $A$, For rat 1 , slope of regression line $=155.4 \mathrm{gold} / \mu \mathrm{m}^{2} . C$, For rat 2 , slope of regression line $=78.1 \mathrm{gold} / \mu \mathrm{m}^{2} . E$, For rat 3, slope of regression line $=153.0$ gold $/ \mu \mathrm{m}^{2} . B, D, F$, The gold particle density (number of particles per square micrometer) for NMDARs is weakly and negatively correlated with synapse size (Spearman rank correlation). the methodological limitations (see Materials and Methods). The monoclonal antibody ab-1F1 to AMPA receptor subunits GluR2/3 and the mixture of antibodies to the NMDAR subunits resulted in double labeling of many synapses for AMPARs and NMDARs (Fig. 4), but numerous synapses labeled with only one receptor, or not labeled at all, were also present in single sections. As expected (Kharazia and Weinberg, 1999; Petralia et al., 1999; Takumi et al., 1999b), the two receptors were colocalized in both large and small synapses.

\section{Tangential distribution of NMDARs across the postsynaptic density}

On average, AMPARs are evenly distributed in hippocampal spine synapses, but NMDARs were shown to occur more frequently in the middle of the postsynaptic density as detected by antibodies to the intracellular domain of the NR1 subunit (Somogyi et al., 1998a,b). To test the consistency of this pattern, we applied the current mixture of antibodies to single sections from rats 1 and 2 . The tangential position of particles was analyzed in synapses that were cut at a plane revealing the synaptic cleft. The distribution of particles for NMDARs was significantly different from uniform distribution ( $p<0.01$, Kolmogorov-Smirnov test). Immunolabeling was more frequent in the middle of the postsynaptic density than toward the edge (Fig. 5).

\section{NMDAR immunoreactivity in the spine apparatus}

Dendritic spines of CA1 pyramidal neurons and other central neurons may contain a membranous organelle called the spine apparatus (Gray, 1959; Peters et al., 1991; Spacek and Harris, 1997) (Fig. 6) that is continuous with the dendritic endoplasmic reticulum. The spine apparatus was frequently and strongly labeled for NMDA receptors (Fig. 6), particularly in large spines containing a large spine apparatus. Immunoreactivity of AMPARs has also been observed in the spine apparatus in CA1 pyramidal cells (Nusser et al., 1998). Colocalization of NMDARs and AMPARs could be demonstrated in the spine apparatus in single sections of large spines, which sometimes were also labeled for both receptors in the synaptic junction (Fig. 6C,D).

\section{NMDAR immunoreactivity in synapses on the dendrites of interneurons}

Although the main focus of the present study was on synapses received by spines, type I synapses were also occasionally found on dendritic shafts. Most of these dendritic shafts originate from GABAergic interneurons that show NMDA receptor-mediated synaptic currents (for review, see Freund and Buzsaki, 1996). Several of the synapses on dendritic shafts were immunopositive for NMDA receptors (Fig. 7). Because of the heterogeneity of interneurons and the low frequency of encountering such dendrites in the present series of photographs, the quantitative evaluation of these synapses was not pursued.

\section{DISCUSSION}

\section{Differential variability of NMDAR and AMPAR content in pyramidal cell spines}

The results confirm some of the data of two recent studies (Petralia et al., 1999; Takumi at al., 1999b) demonstrating that AMPA and NMDA receptors are expressed differentially in the synapses of CA1 pyramidal cells innervated by CA3 pyramidal cells. The three studies agree that in adult rats, virtually all type I synapses are immunopositive for NMDARs, and our direct measurement also confirmed the calculation of Takumi et al. (1999b) that the NMDA receptor content of spine synapses positively correlates with synaptic area. However, this correlation is much weaker than that found for AMPARs (Nusser et al., 1998; Takumi et al., 1999b), as also seen in the present study. The proportion of AMPAR-immunonegative synapses in our measurements was consistently lower (mean = $12 \%)$ than that $(25 \%)$ reported by Takumi et al. (1999b) but was similar to that obtained for a 5-week-old animal [minimum, 9-12\% (Petralia et al., 1999)]. Furthermore, the range of 


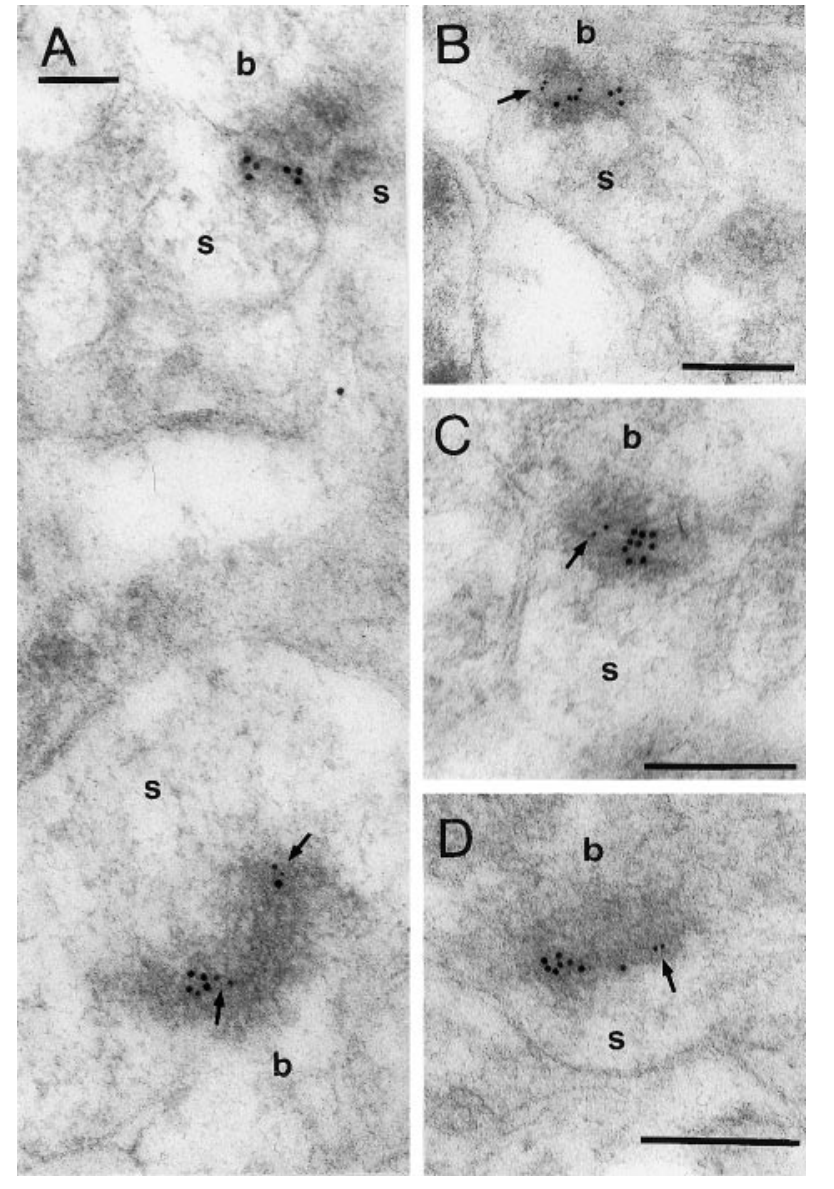

Figure 4. Double immunogold labeling of NMDARs (10 $\mathrm{nm}$ particles) and AMPARs ( $5 \mathrm{~nm}$ particles; arrows) in individual synapses on spines $(s)$ in the stratum radiatum. $b$, Bouton. Scale bars: $A, 0.1 \mu \mathrm{m} ; B-D, 0.2 \mu \mathrm{m}$.

mean labeling of AMPARs in our animals was eight to nine immunoparticles per synapse, higher than that reported previously for a 5-week-old animal (Petralia et al., 1999). The differences may be attributable to the partially different antibodies used, the different tissue processing, and the immunoreaction conditions. The important point is that the AMPARimmunonegative synapse population cannot be considered a distinct population, because (1) the labeling intensity of synapses forms a continuum, (2) the immunogold labeling is inherently stochastic, and (3) even using serial sections, a large part of the synaptic disk remains inaccessible to antibodies because they cannot penetrate into the section. Therefore, using the immunogold method, it is not possible to identify any individual synapse that genuinely lacks AMPARs and to distinguish it from those that remained unlabeled for the reasons listed above. As a result, the unlabeled synapses and those labeled by few immunoparticles must be considered a continuous population. Furthermore, in contrast to previous reports (Kharazia and Weinberg, 1999; Takumi et al., 1999b), our data on the relationship of AMPAR immunoreactivity and synapse size do not indicate a minimal size below which AMPARs can be predicted to be absent. Although the AMPARimmunonegative synapses are all small, in the small-size synapse population all degrees of labeling can be present as reflected by the wide variability of the density of immunoparticles for AMPAR.
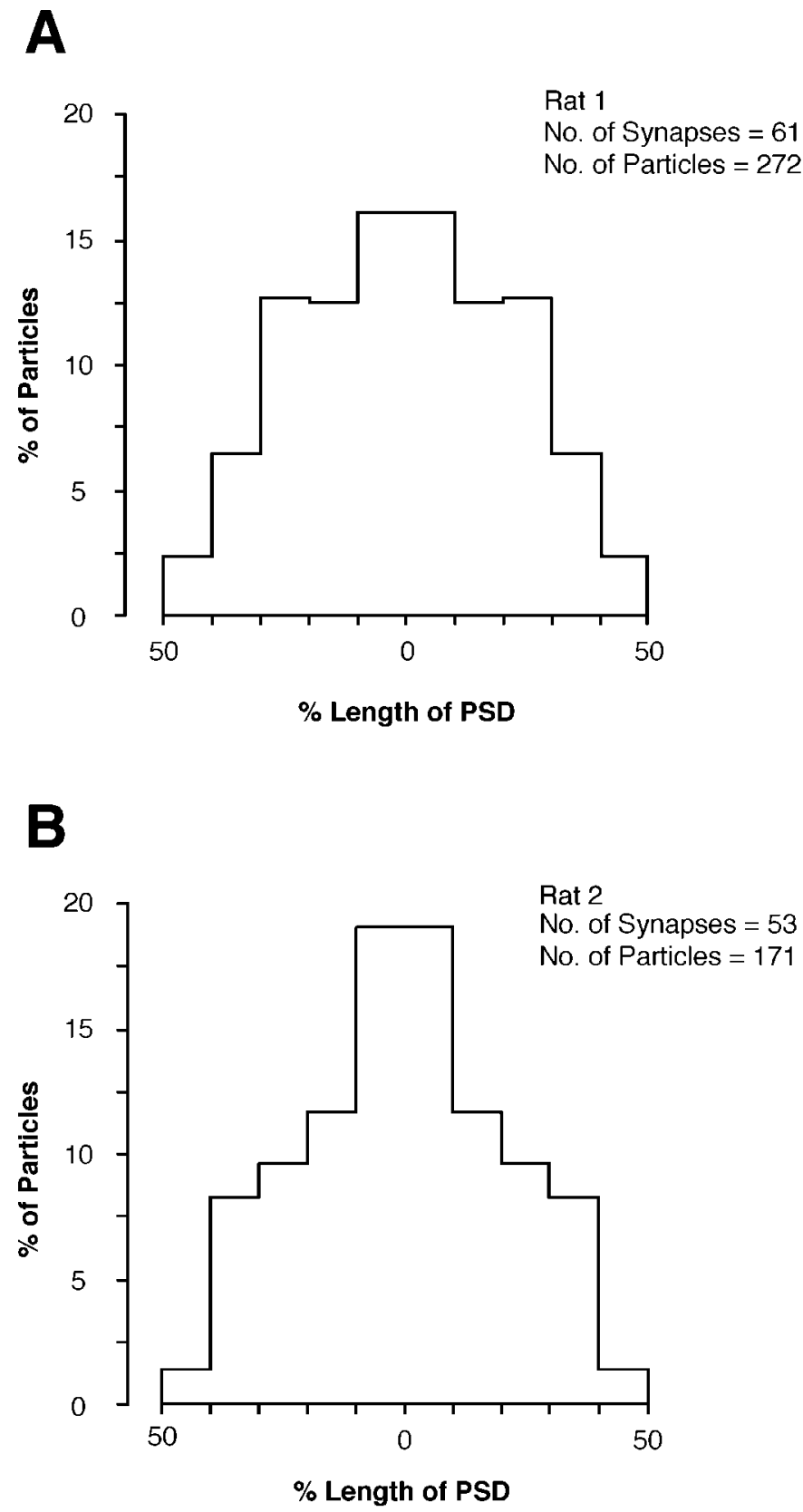

Figure 5. Average tangential distribution of immunogold labeling of NMDARs (mixture of antibodies ab-NR1-pan and ab-NR2A/B) along the postsynaptic density of CA1 pyramidal cell spines in rats $1(A)$ and 2 $(B)$. The radial location of gold particles was measured from the midline of the PSD and normalized across the synapse population having variable size. The distribution obtained was mirrored across the midline for display. Labeling of NMDARs has a higher probability toward the center of the PSD.

Altogether, our results support an independent regulation of AMPAR and NMDAR expression in synapses on CA1 pyramidal cells. The receptor complements of synapses are different according to their size; large synapses express the highest level of both receptors, whereas the small synapses have a very wide range of AMPAR content accompanied by a relatively uniform NMDAR content. Some type I synapses on dendritic shafts of putative GABAergic interneurons were NMDAR immunopositive. Because these synapses are on dendrites of a heterogeneous 

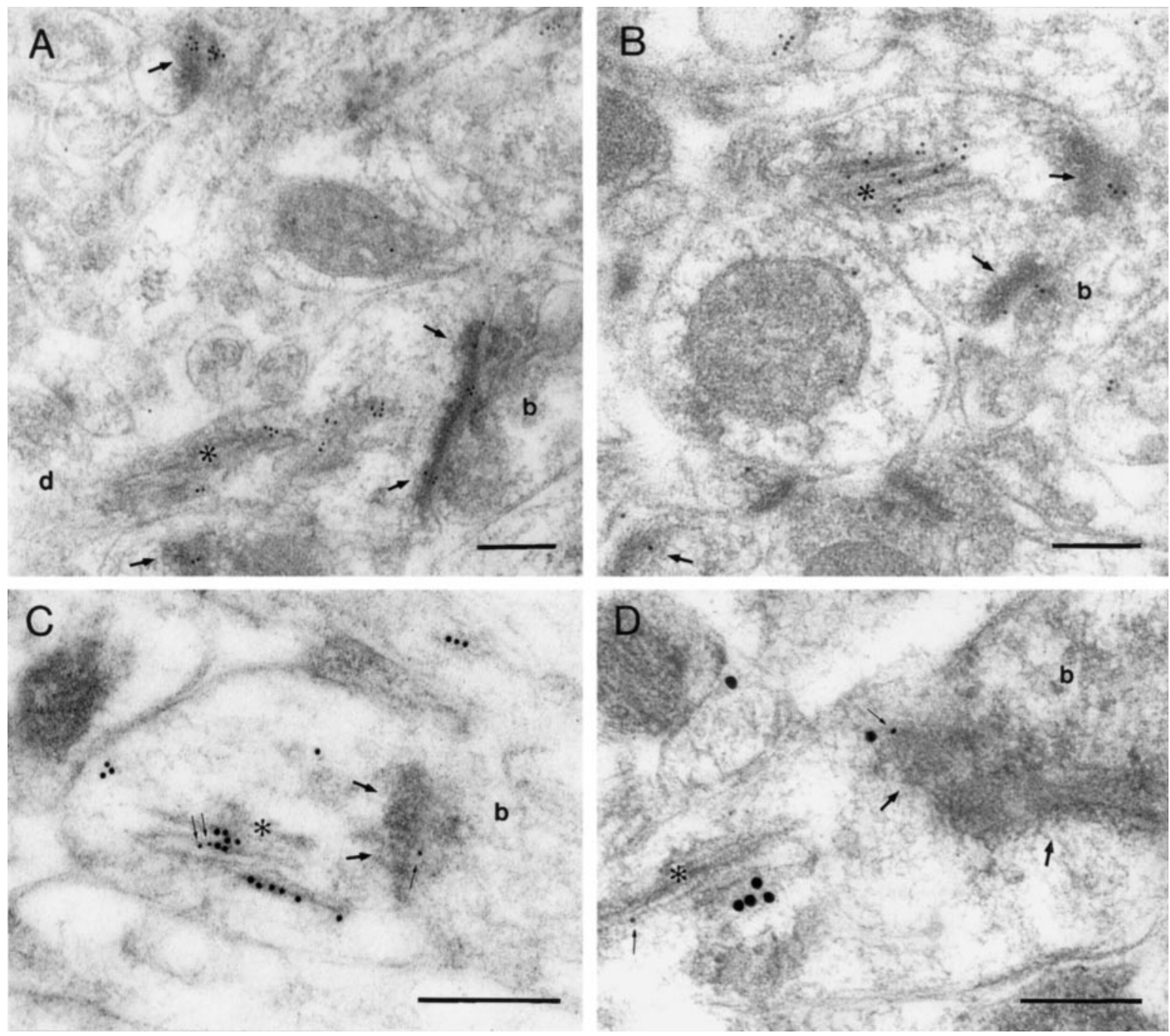

Figure 6. Immunoreactivity of NMDARs and AMPARs in the spine apparatus of hippocampal CA1 pyramidal cells. $A, B$, Gold particles for NMDAR are found in the synaptic junctions (thick arrows) and in the spine apparatus (asterisks) of spines. $C$, D, Double labeling of NMDARs (large particles, $10 \mathrm{~nm}$ in $C$ and $20 \mathrm{~nm}$ in $D$ ) and AMPARs (small particles, $5 \mathrm{~nm}$ in $C$ and $10 \mathrm{~nm}$ in $D$; thin arrows) shows that both receptors are localized in the same spine apparatus. $b$, Bouton; $d$, dendritic shaft. Scale bars, $0.2 \mu \mathrm{m}$.

population of interneurons (Freund and Buzsaki, 1996), the quantitative evaluation of their receptor content was not attempted in the present study.

\section{Tangential distribution of AMPARs and NMDARs in synapses of pyramidal cell spines}

Over the whole population of synapses, on average, NMDARs occur more frequently in the middle of the synaptic disk, although in individual synapses immunoreactivity of NMDARs may occur anywhere. Similar data have been reported previously for the NR1 subunit, using antibodies to the intracellular domain of the subunit in the hippocampus (Somogyi et al., 1998a,b) and in the neocortex (Kharazia and Weinberg, 1997). In contrast, a uniform average distribution of NMDARs was found along the synaptic disk in the neostriatum, globus pallidus, and subthalamic nucleus (Bernard and Bolam, 1998; Clarke and Bolam, 1998). In large hippocampal synapses, individual particles or clusters of particles corresponding to NMDAR immunoreactivity may be present at any position along the postsynaptic density. Therefore, a central peak of NMDAR enrichment in the normalized average size hippocampal synapse is a result of the central position of
NMDA receptors in small synapses, which are the predominant variety of synapses on CA1 pyramidal cells. Similar to the pattern described here, immunogold particle clusters for NMDARs have also been reported in the neocortex, where in small synapses they are also in a central position (Kharazia and Weinberg, 1997, 1999; Valtschanoff et al., 1999). As a hypothesis, it is proposed that in small synapses clusters of NMDA receptors predominate in the center of the synaptic membrane specialization and are accompanied by an even distribution of AMPARs when present, whereas in larger synapses clusters of NMDARs are interspersed in a field of relatively evenly distributed AMPARs. In other regions of the CNS, higher labeling of GluR2/3 subunits has been observed in the outer portion of the synapse (Matsubara et al., 1996; for review, see Takumi et al., 1999a).

Both AMPARs and NMDARs are accompanied by a host of associated anchoring and regulatory proteins specific to each class of receptor (for review, see Sheng and Pak, 1999). Furthermore, AMPARs are transported to synapses before NMDARs in cultured cells (Rao et al., 1998) and are more loosely anchored to the subsynaptic cytoskeleton (Allison et al., 1998). It appears that 

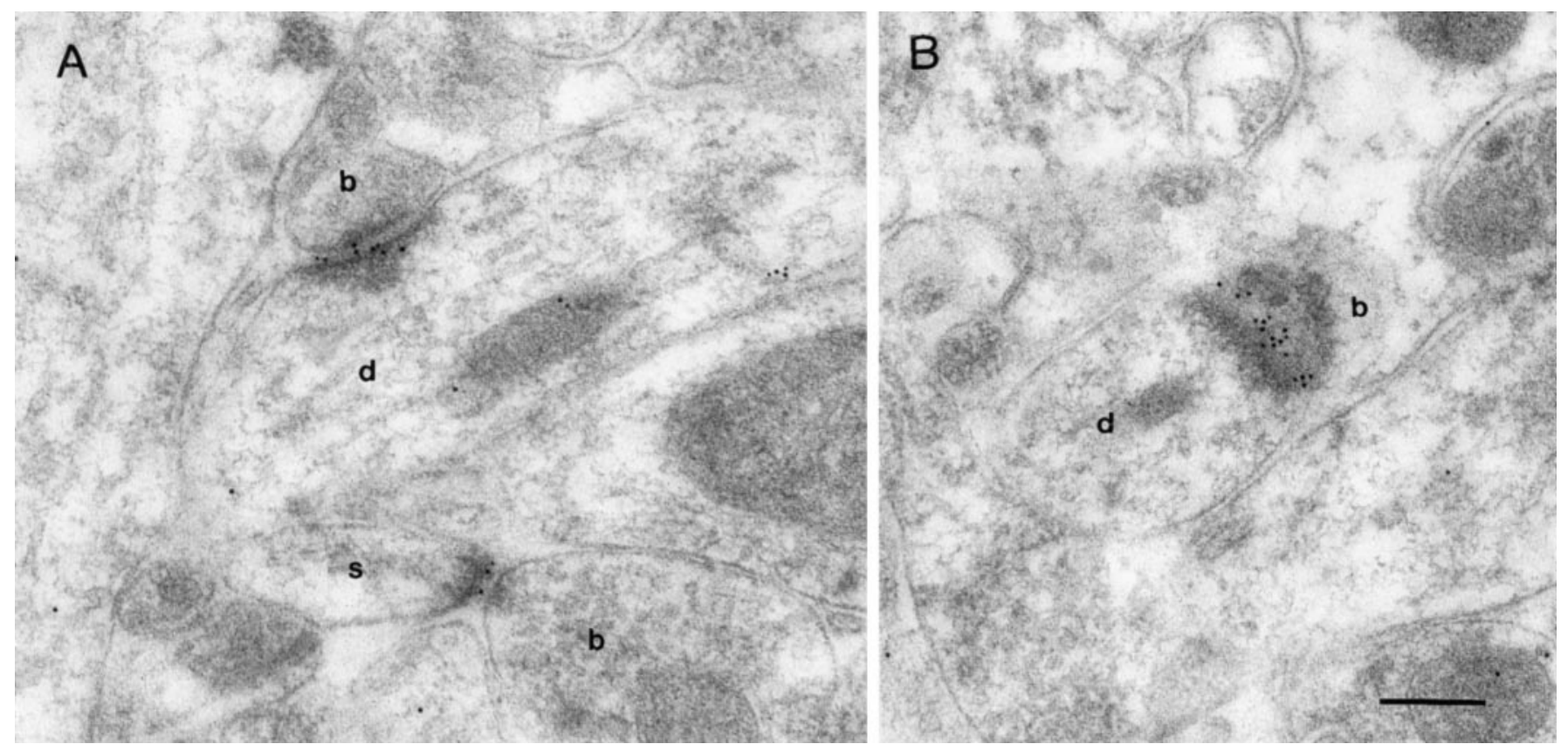

Figure 7. NMDAR-immunopositive synapses on dendritic shafts $(d)$ in stratum radiatum of the CA1 area. $A, B$, Gold particles can also be observed within the dendrite in $A$. The synapse in $B$ is cut tangential. $b$, Bouton; $s$, spine. Scale bar: $A, B, 0.2 \mu \mathrm{m}$.

NMDARs are more tightly anchored to subsynaptic proteins (Allison et al., 1998) and, indirectly via the scaffolding protein PSD95, to the neuronal cell-adhesion molecules neuroligins (Irie et al., 1997; Song et al., 1999). Neuroligins interact with $\beta$-neurexins forming asymmetric intercellular junctions (Peters et al., 1991; Irie et al., 1997; Song et al., 1999). Song et al. (1999) proposed that the interaction of the postsynaptic neuroligin/ PSD95/NMDAR complex with presynaptic $\beta$-neurexins may contribute to the structural stability of synaptic junctions and contribute to the localization of ionotropic GluRs within the PSD. As discussed above, changing synaptic efficacy may involve the synaptic insertion or removal of AMPARs, which may be facilitated by their more even tangential distribution and higher mobility in the PSD compared with the central and more stable location of NMDARs. In summary, because of the distinct regulation and protein-protein interactions of AMPARs and NMDARs, it would make economic sense if they formed segregated microclusters within the synaptic disk (Takumi et al., 1999a).

\section{NMDARs in the spine apparatus}

Immunogold labeling of the NMDARs decorated the cisternae of the spine apparatus, as has also been reported for AMPARs, suggesting a role in synaptic receptor turnover (Nusser et al., 1998). The spine apparatus in large spines, which were most often labeled, is considered to be an extension of the dendritic smooth endoplasmic reticulum (SER) (Spacek and Harris, 1997) to which it is connected through the spine neck. The endoplasmic reticulum and Golgi complex within dendrites and the endoplasmic reticulum in spines have a heterogeneous distribution of receptors, channels, ion pumps, and components of protein synthesis and transport pathways (Takei et al., 1992; Krijnse-Locker et al., 1995; Tiedge and Brosius, 1996; Gardiol et al., 1999). Roles proposed for the spine apparatus include the regulation of calcium concentration within spines (for review, see Berridge, 1998) and involvement in local protein synthesis (Tiedge and Brosius,
1996; Steward, 1997; Gardiol et al., 1999). Furthermore, Spacek and Harris (1997) observed that the SER vesicles and tubules can be in close apposition to the spine plasma membrane and margins of the postsynaptic density and suggested a role for the SER in the addition and recycling of spine membrane. Not all spines contain spine apparatus or SER (Spacek and Harris, 1997), indicating that individual spines might have different rates of NMDAR and AMPAR turnover via these organelles depending on the functional state of the spine.

A hypothesis for local synthesis of the NR2A subunit of the NMDAR has been proposed recently by Quinlan et al. (1999) to explain the rapid expression of new NMDARs that have a high proportion of NR2A subunits when visually deprived rats undergo visual experience. They suggested local translation of new NMDAR subunits in a Golgi-like endosome in spines of neocortical neurons and insertion of the new receptors into the plasma membrane. Such a localization of the protein synthesis would provide a mechanism for changing the NMDAR composition in response to experience. A similar hypothesis can be envisaged for local synthesis of AMPARs. Indeed, mRNAs for subunits of the AMPAR have been found within dendrites of cultured hippocampal cells (Miyashiro et al., 1994). The finding of both AMPARs and NMDARs in the same spine apparatus suggests the possibility that both receptors can be added to or removed from synapses in a dynamic manner. However, because the synaptic receptor content seems to be differentially regulated for the two receptors, some mechanisms must ensure that each of the two receptors can be added or removed from the spine plasma membrane independently of the other one (Luscher et al., 1999).

\section{REFERENCES}

Allison DW, Gelfand VI, Spector I, Craig AM (1998) Role of actin in anchoring postsynaptic receptors in cultured hippocampal neurons: 
differential attachment of NMDA versus AMPA receptors. J Neurosci 18:2423-2436.

Baude A, Nusser Z, Roberts JDB, Mulvihill E, McIlhinney RAJ, Somogyi P (1993) The metabotropic glutamate receptor (mGluR1 $\alpha$ ) is concentrated at perisynaptic membrane of neuronal subpopulations as detected by immunogold reaction. Neuron 11:771-787.

Bernard V, Bolam JP (1998) Subcellular and subsynaptic distribution of the NR1 subunit of the NMDA receptor in the neostriatum and globus pallidus of the rat: co-localization at synapses with the GluR2/3 subunit of the AMPA receptor. Eur J Neurosci 10:3721-3736.

Berridge MJ (1998) Neuronal calcium signaling. Neuron 21:13-26.

Bliss TVP, Collingridge GL (1993) A synaptic model of memory: longterm potentiation in the hippocampus. Nature 361:31-39.

Boyer C, Schikorski T, Stevens CF (1998) Comparison of hippocampal dendritic spines in culture and in brain. J Neurosci 18:5294-5300.

Chazot PL, Stephenson FA (1997) Molecular dissection of native mammalian forebrain NMDA receptors containing the NR1 C2 exon: direct demonstration of NMDA receptors comprising NR1, NR2A, and NR2B subunits within the same complex. J Neurochem 69:2138-2144.

Chazot PL, Cik M, Stephenson FA (1995) An investigation into the role of N-glycosylation in the functional expression of a recombinant heteromeric NMDA receptor. Mol Membr Biol 12:331-337.

Clarke NP, Bolam JP (1998) Distribution of glutamate receptor subunits at neurochemically characterized synapses in the entopeduncular nucleus and subthalamic nucleus of the rat. J Comp Neurol 397:403-420.

Collingridge GL, Kehl SJ, McLennan H (1983) Excitatory amino acids in synaptic transmission in the Schaffer collateral-commissural pathway of the rat hippocampus. J Physiol (Lond) 334:33-46.

Durand GM, Kovalchuk Y, Konnerth A (1996) Long-term potentiation and functional synapse induction in developing hippocampus. Nature 381:71-75.

Freund TF, Buzsaki G (1996) Interneurons of the hippocampus. Hippocampus 6:347-470.

Gallo V, Upson LM, Hayes WP, Vyklicky L, Winters CA, Buonanno A (1992) Molecular cloning and developmental analysis of a new glutamate receptor subunit isoform in cerebellum. J Neurosci 12:1010-1023.

Gardiol A, Racca C, Triller A (1999) Dendritic and postsynaptic protein synthetic machinery. J Neurosci 19:168-179.

Gomperts SN, Rao A, Craig AM, Malenka RC, Nicoll RA (1998) Postsynaptically silent synapses in single neuron cultures. Neuron 21:1443-1451.

Gray EG (1959) Axo-somatic and axo-dendritic synapses of the cerebral cortex: an electron microscope study. J Anat 93:420-433.

Harris KM, Stevens JK (1989) Dendritic spines of CA1 pyramidal cells in the rat hippocampus: Serial electron microscopy with reference to their biophysical characteristics. J Neurosci 9:2982-2997.

Harris KM, Kater SB (1994) Dendritic spines: cellular specializations imparting both stability and flexibility to synaptic function. Annu Rev Neurosci 17:341-371.

Hayat MA (1989) Principles and techniques of electron microscopy. London: MacMillan.

Irie M, Hata M, Takeuchi M, Ichtchenko K, Toyoda A, Hirao K, Takai Y, Rosahl TW, Sudhof TC (1997) Binding of neuroligins to PSD-95. Science 277:1511-1515.

Isaac JTR, Nicoll RA, Malenka RC (1995) Evidence for silent synapses: implications for the expression of LTP. Neuron 15:427-434.

Kharazia VN, Weinberg RJ (1997) Tangential synaptic distribution of NMDA and AMPA receptors in rat neocortex. Neurosci Lett 238:41-44.

Kharazia VN, Weinberg RJ (1999) Immunogold localization of AMPA and NMDA receptors in somatic sensory cortex of albino rat. J Comp Neurol 412:292-302.

Krijnse-Locker J, Parton RG, Fuller SD, Griffiths G, Dotti CG (1995) The organization of the endoplasmic reticulum and the intermediate compartment in cultured rat hippocampal neurons. Mol Biol Cell 6:1315-1332.

Kullmann DM (1994) Amplitude fluctuations of dual-component EPSCs in hippocampal pyramidal cells: implications for long-term potentiation. Neuron 12:1111-1120.

Liao D, Hessler NA, Malinow R (1995) Activation of postsynaptically silent synapses during pairing-induced LTP in CA1 region of hippocampal slice. Nature 375:400-404.
Liao DH, Zhang X, O’Brien R, Ehlers MD, Huganir RL (1999) Regulation of morphological postsynaptic silent synapses in developing hippocampal neurons. Nat Neurosci 2:37-43.

Luscher C, Xia H, Beattie EC, Carroll RC, Zastrow M, Malenka RC, Nicoll RA (1999) Role of AMPA receptor cycling in synaptic transmission and plasticity. Neuron 24:649-658.

Malenka RC, Nicoll RA (1997) Silent synapses speak up. Neuron 19:473-476.

Matsubara A, Laake JH, Davanger S, Usami S, Ottersen OP (1996) Organization of AMPA receptor subunits at a glutamate synapse: a quantitative immunogold analysis of hair cell synapses in the rat organ of Corti. J Neurosci 16:4457-4467.

Miyashiro K, Dichter M, Eberwine J (1994) On the nature and differential distribution of mRNAs in hippocampal neurites: implications for neuronal functioning. Proc Natl Acad Sci USA 91:10800-10804.

Monyer H, Burnashev N, Laurie DJ, Sakmann B, Seeburg PH (1994) Developmental and regional expression in the rat brain and functional properties of four NMDA receptors. Neuron 12:529-540.

Nusser Z (1999) A new approach to estimate the number, density and variability of receptors at central synapses. Eur J Neurosci 11:745-752.

Nusser Z, Mulvihill E, Streit P, Somogyi P (1994) Subsynaptic segregation of metabotropic and ionotropic glutamate receptors as revealed by immunogold localisation. Neuroscience 61:421-427.

Nusser Z, Roberts JDB, Baude A, Richards JG, Somogyi P (1995) Relative densities of synaptic and extrasynaptic $\mathrm{GABA}_{\mathrm{A}}$ receptors on cerebellar granule cells as determined by a quantitative immunogold method. J Neurosci 15:2948-2960.

Nusser Z, Lujan R, Laube G, Roberts JDB, Molnar E, Somogyi P (1998) Cell type and pathway dependence of synaptic AMPA receptor number and variability in the hippocampus. Neuron 21:545-559.

O’Brien RJ, Kamboj S, Ehlers MD, Rosen KR, Fischbach GD, Huganir RL (1998) Activity-dependent modulation of synaptic AMPA receptor accumulation. Neuron 21:1067-1078.

Ottiger H-P, Gerfin-Moser A, Del Principe F, Dutly F, Streit P (1995) Molecular cloning and differential expression patterns of avian glutamate receptor mRNAs. J Neurochem 64:2413-2426.

Peters A, Palay SL, Webster HdeF (1991) The fine structure of the nervous system. New York: Oxford UP.

Petralia RS, Yokotani N, Wenthold RJ (1994a) Light and electron microscope distribution of the NMDA receptor subunit NMDAR1 in the rat nervous system using a selective anti-peptide antibody. J Neurosci 14:667-696.

Petralia RS, Wang Y-X, Wenthold RJ (1994b) The NMDA receptor subunits NR2A and NR2B show histological and ultrastructural localization patterns similar to those of NR1. J Neurosci 14:6102-6120.

Petralia RS, Esteban JA, Wang Y-X, Partridge JG, Zhao H-M, Wenthold RJ, Malinow R (1999) Selective acquisition of AMPA receptors over postnatal development suggests a molecular basis for silent synapses. Nat Neurosci 2:31-36.

Quinlan EM, Philpot BD, Huganir RL, Bear MF (1999) Rapid, experience-dependent expression of synaptic NMDA receptors in visual cortex in vivo. Nat Neurosci 2:352-357.

Rao A, Kim E, Sheng M, Craig AM (1998) Heterogeneity in the molecular composition of excitatory postsynaptic sites during development of hippocampal neurons in culture. J Neurosci 18:1217-1229.

Sheng M, Pak DT (1999) Glutamate receptor anchoring proteins and the molecular organization of excitatory synapses. Ann NY Acad Sci 868:483-493.

Shepherd GMG, Harris KM (1998) Three-dimensional structure and composition of CA3 $\rightarrow$ CA1 axons in rat hippocampal slices: implications for presynaptic connectivity and compartmentalization. J Neurosci 18:8300-8310.

Shi S-H, Hayashi Y, Petralia RS, Zaman SH, Wenthold RJ, Svoboda K, Malinow R (1999) Rapid spine delivery and redistribution of AMPA receptors after synaptic NMDA receptor activation. Science 284:1811-1816.

Somogyi P, Tamas G, Lujan R, Buhl EH (1998a) Salient features of synaptic organisation in the cerebral cortex. Brain Res Rev 26:113-135.

Somogyi P, Nusser Z, Roberts JDB, Lujan R (1998b) Precision and variability in the placement of pre- and postsynaptic receptors in relation to neurotransmitter release sites. In: Central synapses: 
quantal mechanisms and plasticity, Workshop IV (Faber DS, Korn H, Redman SJ, Thompson SM, Altman JS, eds), pp 82-93. Strasbourg, France: Human Frontier Science Program.

Song J-Y, Ichtchenko K, Sudhof TC, Brose N (1999) Neuroligin 1 is a postsynaptic cell-adhesion molecule of excitatory synapses. Proc Natl Acad Sci USA 96:1100-1105.

Spacek J, Harris KM (1997) Three-dimensional organization of smooth endoplasmic reticulum in hippocampal CA1 dendrites and dendritic spines of the immature and mature rat. J Neurosci 17:190-203.

Steward O (1997) mRNA localization in neurons: a multipurpose mechanism? Neuron 18:9-12.

Takei K, Stukenbrok H, Metcalf A, Mignery GA, Sudhof TC, Volpe P, De Camilli P (1992) $\mathrm{Ca}^{2+}$ stores in Purkinje neurons: endoplasmic reticulum subcompartments demonstrated by the heterogenous distribution of the $\mathrm{InsP}_{3}$ receptor, $\mathrm{Ca}^{2+}$-ATPase, and calsequestrin. J Neurosci 12:489-505.
Takumi Y, Matsubara A, Rinvik E, Ottersen OP (1999a) The arrangement of glutamate receptors in excitatory synapses. Ann NY Acad Sci 868:474-482.

Takumi Y, Ramirez-Leon V, Laake P, Rinvik E, Ottersen OP (1999b) Different modes of expression of AMPA and NMDA receptors in hippocampal synapses. Nat Neurosci 2:618-624.

Tiedge H, Brosius J (1996) Translational machinery in dendrites of hippocampal neurons in culture. J Neurosci 16:7171-7181.

Valtschanoff JG, Burette A, Wenthold RJ, Weinberg RJ (1999) Expression of NR2 receptor subunit in rat somatic sensory cortex: synaptic distribution and colocalization with NR1 and PSD-95. J Comp Neurol 410:599-611.

Wenthold RJ, Yokotani N, Doi K, Wada K (1992) Immunochemical characterization of the non-NMDA glutamate receptor using subunitspecific antibodies. Evidence for a hetero-oligomeric structure in rat brain. J Biol Chem 267:501-507. 